\title{
Development of a simultaneous amplification and testing (SAT) system based fluorescence real-time isothermal RNA amplification for rapid detection of Cronobacter spp. in powdered infant formula
}

\section{Riqin Wu}

Jianyuan Science \& Technology Co. Ltd.

\section{Xiaojiao Song}

Jianyuan Science \& Technology Co. Ltd.

Xiaoping Gong

Jianyuan Science \& Technology Co. Ltd.

\section{Gang Wang}

Jianyuan Science \& Technology Co. Ltd.

\section{Xinsheng Wang}

Jianyuan Science \& Technology Co. Ltd.

\section{Wolong Ma}

Jianyuan Science \& Technology Co. Ltd.

\section{Luan Zhang}

Jianyuan Science \& Technology Co. Ltd.

\section{Qijun Liu}

Chinese Academy of Agricultural Sciences Institute of Food Science and Technology

Xifu Liu

Jianyuan Science and Technology Co.Ltd.

\section{Fuguo Xing ( $\nabla$ xingfuguo@caas.cn )}

Chinese Academy of Agricultural Sciences Institute of Food Science and Technology https://orcid.org/0000-0002-9078-6523

Original article

Keywords: Cronobacter spp., Cronobacter sakazakii, SAT assay, Detection, Food safety, Viable bacteria

Posted Date: May 6th, 2020

DOI: https://doi.org/10.21203/rs.3.rs-25712/v1 
License: (c) (i) This work is licensed under a Creative Commons Attribution 4.0 International License. Read Full License 


\section{Abstract}

Contamination of Cronobacter spp. in powdered infant formulas is a severe food safety problem. The present study developed a rapid and sensitive Simultaneous Amplification and Testing (SAT) system for the detection of Cronobacterspp. in powdered infant formula. SAT detection system is based on fluorescence real-time isothermal RNA amplification and mainly includes pre-enrichment, RNA isolation and detection by fluorescence real-time RNA isothermal amplification. The amplification targets $16 \mathrm{~s} / 23 \mathrm{~s}$ rRNA for the specific detection and rapid identification of Cronobacter spp. and can accurately detect viable strains in infant formulas and other food products. Here, six $C$. sakazakii strains and 25 references strains were examined using one pair of primers, having the accuracy of $100 \%$ in reference to conventional methods like ISO-IDF 22964 and real-time PCR. The SAT assay was proved to be highly sensitive with a detection limit of $10^{2} \mathrm{CFU} / \mathrm{mL}$ without pre-enrichment for powdered infant formula. After $3 \mathrm{~h}, 4 \mathrm{~h}$ and $8 \mathrm{~h}$ enrichment, the sensitivity was increased up to $10^{0}, 10^{-1}$ and $10^{-3} \mathrm{CFU} / \mathrm{mL}$ of Cronobacter spp., respectively. The SAT system including pre-enrichment performed for Cronobacterspp. detection was less than $4 \mathrm{~h}$, dramatically shortened, in comparison to several days using standard culturing method and overnight using pre-enrichment real-time PCR method. And more importantly, the SAT assay can accurately distinguish viable strains from the dead one. Taken together, the SAT assay combined with pre-enrichment established in the present study should provide a rapid, sensitive, efficient and specific method for direct detection of Cronobacterspp. in powdered infant formula. Moreover, a full automatic food-borne pathogenic bacteria detector was developed based on the SAT assay.

\section{Introduction}

Neonatal infections caused by Cronobacter spp. (formerly Enterobacter sakazakii) have been reported from different parts of the world. Cronobacter causes meningitis and necrotizing enterocolitis in infants, and septicemia and catheter-associated infections in immunocompromised people and elderly, with mortality rates ranging from 10 to $80 \%$ (Mullane et al. 2007). All Cronobacter spp. have been associated with human infections excepted $C$. condiment (Cruz-Córdova et al. 2012). Cronobacterspp. is a group of Gram-negative pathogenic bacteria belonging to the family Enterobacteriacea, which can survive in the intestine of humans and animals. The multi-species complex is typically facultative anaerobic, catalasepositive, oxidase-negative, motile, rod-shaped, non-spore forming bacteria that can produce a yellow pigment. Although Cronobacter can be rehabilitated through the use of antibiotics, the mortality rate of infection caused by the bacteria is up to $50 \%$, accompanied by severe neurological sequelae, developmental disorders and other symptoms.

It has been reported that Cronobacterspp. are highly diverse and share many phenotypic traits with other Enterobacteraceae members (Jaradat et al. 2009). They are markedly resistant to osmotic stress and dryness and moderately thermotolerant (Jaradat et al. 2009). For example, some encapsulated Cronobacterspp. were still recoverable from desiccated infant formula after 2.5-year-storage (Barron and Forsythe 2007; Breeuwer et al. 2003). It is also known to survive for 2 years in the powdered infant formula (PIF) at low water activity (Edelson-Mammel et al. 2005). In addition, the growth of this group of 
microorganisms has also been recorded in PIF reconstituted at temperatures ranging from 8 to $47^{\circ} \mathrm{C}$ (Iversen et al. 2008). Therefore, the potential risk of $C$. sakazakii contamination during the preparation of PIF is considered high (O'Brien et al. 2009).

Cronobacterspp. contaminated PIFs was identified as the source of infection (Friedemann 2009). For PIF, current microbiological criteria require the absence of all seven Cronobacter species in 30 samples of $10 \mathrm{~g}$ (Codex Alimentarius Commission 2008; Jackson and Forsythe 2016). The losses caused by Cronobacter can be significant for manufacturers. For example, in 2011, a suspected outbreak of $C$. sakazakii in the United States led to product recalls and a subsequent 10\% drop in the manufacturers' shares although the laboratory evidence to linking their product to infant infections and deaths was lack (Centers for Disease Control 2016; Geller 2011; Jackson and Forsythe 2016). Moreover, the costs of infection are also high because of the long-term influences of the disease like life-long brain damage. It was estimated that the cost of $C$. sakazakii infections was more than $\$ 5$ million per case (Minor et al. 2015). Taken together, the losses and costs of $C$. sakazakii infections from PIFs are enormous.

A variety of biological techniques have been developed for detection of Cronobacter spp., including the traditional isolation and biochemical identification after enrichment, or differential screening medium. Culture dependent isolation and assay methods for complete analysis of Cronobacter spp. are timeconsuming and laborious (International Organization for Standardization 2006a; Chen 2012). In addition, several molecular methods have been reported, including conventional PCR assay using $16 \mathrm{~s}$ rRNA (Lehner et al. 2004), OmpA or rpoB genes (Mohan Nair and Venkitanarayanan 2006; Stoop et al. 2009), real-time PCR using OmpA (Cai et al. 2013; Zimmermann et al. 2014), the fluorescence in situ hybridization (FISH) using a novel peptide nucleic acid probe (Almeida et al. 2009) and the loop-mediated isothermal amplification (LAMP) using 16S/23S rDNA (Liu et al. 2012). Although the molecular methods offer efficient approaches for the rapid detection of Cronobacter, they are still unfeasible for on-site inspection due to the requirement of professional equipment and expensive labelled probe and the costing of time. Moreover, LAMP may have high risk of amplicon contamination (Cai et al. 2013).

In order to rapidly and accurately identify viable Cronobacterspecies in PIF and its associated environment, in the present study, a real time fluorescent reverse transcription loop-mediated isothermal amplification system (RT-LAMP) targeting 16S/23S rRNA were developed using the simultaneous amplification and testing (SAT) technique. For SAT technique, RNA is used as a template to amplify at isothermal condition $42{ }^{\circ} \mathrm{C}$, and the amplification products are mixtures of RNA and DNA with high efficiency. It has the advantages of less test time $(2 \sim 12 \mathrm{~h})$, higher accuracy and no pollution, and has the ability to distinguish between dead and live bacteria.

\section{Materials And Methods}

\section{Bacterial strains, Pre-Enrichment and media}

The 6 reference strains of Cronobacter spp. used in this study were purchased from China Center of Industrial Culture Collection (CICC). Other 25 non-Cronobacter reference strains (Table 1) including 
Citrobacter, Enterobacter, Escherichia, Klebsiella, Listeria, Proteus, Pseudomonas, Salmonella, Shigella, Vibrio and Yersinia, were obtained from CICC \American Type Culture Collection (ATCC) and National Center for Medical Culture Collections (CMCCB). All the stains were maintained on Luria-Bertani (LB) plates. In order to recover bacteria strains, aliquots of $1 \mathrm{~mL}$ of the enrichment broth were aseptically added to $9 \mathrm{~mL}$ of $\mathrm{LB}$ broth, and incubated at $37^{\circ} \mathrm{C}$ for 8-12 h. After incubation, the amount of colonies was calculated.

\section{Total RNA extraction}

Single colony was picked up from agar plate and inoculated into $3 \mathrm{~mL} L B$ broth in a flask. Each bacteria was incubated at $37^{\circ} \mathrm{C}$ for $12 \mathrm{~h}$ with shaking at $150 \mathrm{rpm}$. Total RNA of all strains was isolated using Bacterial RNA Kit according to the manufacturer's instructions (Omega Bio-tek, Norcross, GA. USA). After treatment with RNase-free DNase I (Omega Bio-tek), RNA samples were measured using a Beckman DU800 (Beckman, Indianapolis, IN, USA) (Lv et al. 2019). Genomic DNA of all strains was extracted using Bacterial DNA Kit according to the manufacturer's instructions (Omega Bio-tek).

\section{Development of a simultaneous amplification and testing (SAT) system}

SAT reaction was performed in a total $40 \mu \mathrm{L}$ mixture consisted of $1 \mu \mathrm{L}$ of M-MuLV reverse $(200 \mathrm{U} / \mu \mathrm{L}$, Roche, Basel, Switzerland), $2 \mu \mathrm{L}$ of T7 RNA Polymerase (200 U/ $\mu \mathrm{L}), 4 \mathrm{mM} \mathrm{MgCl} 2,0.4 \mathrm{mM} \mathrm{dNTP} /$ analog mixture for each, $0.5 \mathrm{mM}$ of each NTP, $0.5 \mathrm{mM}$ of primers for each (SAT-CF: $5^{\prime}$ -

TGACATCCAGAGAATCCTG-3' and SAT-CR: 5'- ACAACATTTCACAACACGAGCC-3'), $0.5 \mathrm{mM}$ probe (5'CACCGAGATGCGGGAGTGCGGTG-3'), and $1 \mu \mathrm{L}$ of RNA template. Thermal cycling parameters were as follows: $60^{\circ} \mathrm{C}, 10 \mathrm{~min} ; 42^{\circ} \mathrm{C}, 5 \mathrm{~min} ; 60$ cycles of amplification at $42{ }^{\circ} \mathrm{C}$ for $50 \mathrm{~s}$. And, the fluorescence was collected at the end of each cycle.

\section{Real-Time PCR reaction conditions}

Real-time PCR reaction was performed in a total $25 \mu \mathrm{L}$ mixture containing $0.5 \mu \mathrm{L}$ of Taq DNA polymerase, $4 \mathrm{mM} \mathrm{MgCl}_{2}, 0.4 \mathrm{mM}$ of each dNTP, $0.5 \mathrm{mM}$ of each NTP, $0.5 \mathrm{mM}$ each primer (RT-CF: 5'-

GGCGAGCGGCGAATATTAT-3' and RT-CR: 5'-CGGGTTTTCCCAGTTGAGATC-3'), 0.5 mM probe (5'-FAMCACCAGTTTTCGGTGCGCCAGC-BHQ-3'), and $2 \mu \mathrm{L}$ of DNA template. The PCR was carried out according to the follow parameters: a denaturation at $37{ }^{\circ} \mathrm{C}$ for $5 \mathrm{~min}$, a denaturation at $95^{\circ} \mathrm{C}$ for $3 \mathrm{~min}$, then 40 cycles of denaturation at $95^{\circ} \mathrm{C}$ for $5 \mathrm{~s}$, annealing at $60{ }^{\circ} \mathrm{C}$ for $40 \mathrm{~s}$.

\section{Specificity of the SAT for C. sakazakii}

To evaluate the specificity of SAT assay, 6 C. sakazakii strains and 25 reference strains were cultured in Luria-Bertani (LB) broth at $37^{\circ} \mathrm{C}$ for $16-18 \mathrm{~h}$ to about $10^{8} \mathrm{CFU} / \mathrm{mL}$. All bacteria strains were counted on LB agar plate at $37^{\circ} \mathrm{C}$ overnight. The ten-fold serial dilutions $\left(10^{7}-10^{0} \mathrm{CFU} / \mathrm{mL}\right)$ were obtained using saline solution. Total RNA of all bacterial strains was extracted as described above and used as template in the subsequent SAT test. The specificity of the results was based on the melting curve analysis and 
real-time PCR amplification curve. Moreover, the sequence of the amplicons was further confirmed via sequencing (Sangon Biotech, Beijing, China) and was subsequently aligned with corresponding sequences available in Genbank.

To evaluate the anti-interference properties of the $C$. sakazakii primers and probes, different bacteria were selected for the SAT system interference test. Twenty-five reference bacterial strains were mixed as group A. Then the above 25 strains were mixed with 6 C. sakazakii strains as group B. Total RNA of these strains was extracted as described above and used as template for the SAT reaction system.

\section{Sensitivity of SAT for C. sakazakii}

\section{Sensitivity of SAT for C. sakazakii in LB broth}

The $C$. sakazakii strains were incubated in LB broth at $37^{\circ} \mathrm{C}$ for $8 \mathrm{~h}$ to about $10^{8} \mathrm{CFU} / \mathrm{mL}$. Bacteria were counted on LB agar plate at $37^{\circ} \mathrm{C}$ overnight. Then, the serial ten-fold dilutions $\left(10^{7}-10^{0} \mathrm{CFU} / \mathrm{mL}\right)$ of bacterial suspensions were obtained using saline solution in triplicate. Total RNA of $C$. sakazakii suspensions $\left(10^{7}-10^{0} \mathrm{CFU} / \mathrm{mL}\right)$ was extracted and used as template for SAT assay.

\section{Sensitivity of SAT for C. sakazakii in powered infant formula}

Artificially PIF contaminated with $C$. sakazakii were prepared by directly spiking with $C$. sakazakii under double-blind conditions. The raw infant formula were confirmed to be negative for $C$. sakazakii by selective plating and routine biochemical testing. Then, $100 \mathrm{~g}$ of contaminated powdered infant formula were added to $900 \mathrm{~mL}$ of buffered peptone water (BPW, pH 7.2) medium (Oxoid, UK) as infant formula broth. The concentration of $C$. sakazakii in each contaminated sample was determined using plating approaches on LB agar plates after overnight incubation at $37^{\circ} \mathrm{C}$. Then, the serial ten-fold dilutions $\left(10^{7}-\right.$ $10^{0} \mathrm{CFU} / \mathrm{mL}$ ) were prepared using infant formula liquid medium in triplicate. Total RNA of $C$. sakazakii in the serial dilutions $\left(10^{7}-10^{0} \mathrm{CFU} / \mathrm{mL}\right)$ were extracted and used as template for SAT assay.

\section{Sensitivity of SAT combined with preenrichment for C. sakazakii in powdered infant formula}

The $C$. sakazakii was incubated in LB broth at $37^{\circ} \mathrm{C}$ for $8 \mathrm{~h}$ to about $10^{8} \mathrm{CFU} / \mathrm{mL}$. The concentration of bacteria was determined using plating approaches after overnight incubation at $37^{\circ} \mathrm{C}$. Then, the serial ten-fold serial dilutions $\left(10^{3}-10^{0} \mathrm{CFU} / \mathrm{mL}, 10^{0} \mathrm{CFU} / 10 \mathrm{~mL}, 10^{0} \mathrm{CFU} / 100 \mathrm{~mL}, 10^{0} \mathrm{CFU} / 1000 \mathrm{~mL}\right.$ ) were prepared using infant formula broth in triplicate and incubated at $37{ }^{\circ} \mathrm{C}$ for $10 \mathrm{~h}$. Every hour, $200 \mu \mathrm{L}$ of each culture was collected, then total RNA was extracted and SAT assay was performed in triplicate.

\section{Sensitivity Comparison of SAT and Real-Time PCR}

To compare the detection limits between SAT and real-time PCR, the $C$. sakazakii incubation, serial dilution and RNA extraction were performed according to the method described in 2.6.1. The $C$. sakazakii was detected using SAT and real-time PCR in the same condition. Furthermore, the serial dilutions (10 ${ }^{7}$ - 
$10^{\circ} \mathrm{CFU} / \mathrm{mL}$ ) were autoclaved at $121^{\circ} \mathrm{C}$ for $30 \mathrm{~min}$ and then stayed at room temperature for $12 \mathrm{~h}$. The $C$. sakazakii was detected to compare the detection of live and killed bacteria SAT and real-time PCR under same condition.

To compare the sensitivity between SAT and real-time PCR with pre-enrichment step, the serial ten-fold dilutions of $C$. sakazakii in BPW were incubated at $37^{\circ} \mathrm{C}$ for $10 \mathrm{~h}$ according to the method described in 2.6.3. Then, SAT and real-time PCR were conducted in the same condition.

\section{Results}

\section{Specificity and covering of the SAT primers for C. sakazakii}

The specificity of the $16 / 23 S$ rRNA primers was evaluated using 6 C. sakazakii strains and 25 reference strains. Only strains of $C$. sakazakii produced positive signal. All the non-C. sakazakii strains had no amplification curve before 60 cycles (Fig. 1A). As shown in Fig. 1B, the mixed strains of $C$. sakazakii and non-C. sakazakii (group B) produced positive signal while the mixed culture of non-C. sakazakii strains (group A) had no amplification signal before 60 cycles. Furthermore, all tested 6 C. sakazakii strains could produce amplification signal using the 16/23S rRNA primers (Fig. 1C). These results suggested that the SAT primers designed in this study were specific to $C$. sakazakii identification and had a good covering for the detection of different $C$. sakazakii isolates.

\section{Sensitivity of SAT for the detection of C. sakazakii in pure culture and in powered infant formula}

Using pure culture samples artificially contaminated with $C$. sakazakii ten-fold serial dilutions were performed by dissolved into LB broth at $10-10^{7} \mathrm{CFU} / \mathrm{mL}$ to assay the analytical sensitivity. The results indicated that the limit of detection of samples without pre-enrichment was $10 \mathrm{CFU} / \mathrm{mL}$ (Fig. 2A). For PIFs artificially contaminated with $C$. sakazakii ten-fold serial dilutions $\left(10-10^{7} \mathrm{CFU} / \mathrm{mL}\right)$, the limit of detection (LOD) of samples without pre-enrichment was $10^{2} \mathrm{CFU} / \mathrm{mL}$ (Fig. 2B).

\section{Sensitivity Comparison of SAT and Real-Time PCR}

\section{Comparison of detection limits between SAT and Real-Time PCR}

To compare the detection limits between SAT and Real-time PCR, a series of ten-fold dilutions with $10^{0}$ $10^{7} \mathrm{CFU} / \mathrm{mL}$ of $C$. sakazakii were prepared and analyzed. For $C$. sakazakii in pure culture, the detection limit of SAT and real-time PCR was $10 \mathrm{CFU} / \mathrm{mL}$ (Fig. 3A) and $10^{3} \mathrm{CFU} / \mathrm{mL}$ (Fig. 3B), respectively.

\section{Comparison of detection limits between SAT and Real-Time PCR with enrichment step}

As shown in Table 2, PIF containing $10^{\circ} \mathrm{CFU} / \mathrm{mL}$ of $C$. sakazakii could be detected successfully by SAT after $3 \mathrm{~h}$ enrichment at $37^{\circ} \mathrm{C}$. For $10^{-1} \mathrm{CFU} / \mathrm{mL}$ of $C$. sakazakii, $4 \mathrm{~h}$ enrichment was needed. After $8 \mathrm{~h}$ enrichment, $10^{-3} \mathrm{CFU} / \mathrm{mL}$ of $C$. sakazakii in PIF could be detectable successfully by SAT. Whereas, for 
real-time PCR, the detection limit of $10^{\circ} \mathrm{CFU} / \mathrm{mL}$ of $C$. sakazakii in PIF was obtained after $5 \mathrm{~h}$ enrichment at $37^{\circ} \mathrm{C}$. For $10^{-1}$ and $10^{-3} \mathrm{CFU} / \mathrm{mL}$ of $C$. sakazikii, $6 \mathrm{~h}$ and $10 \mathrm{~h}$ enrichment was needed, respectively. The results suggested that the pre-enrichment step was necessary for rapid detection of $C$. sakazakii in food samples (Liu et al. 2006; Mohan Nair and Venkitanarayanan 2006; Ye et al. 2012).

\section{Comparison of viable bacteria detection between SAT and Real-Time PCR}

To determine the limit of SAT and real-time PCR in viable bacteria detection, the C. sakazakii $\left(10^{7}-10^{0}\right.$ $\mathrm{CFU} / \mathrm{mL}$ ) was autoclaved at $121^{\circ} \mathrm{C}$ for 30 minutes and then stayed at room temperature for $12 \mathrm{~h}$. As shown in Fig. 4, the detection limit of SAT (Fig. 4A) and real-time PCR (Fig. 4B) was $10^{6} \mathrm{CFU} / \mathrm{mL}$ and $10^{3}$ $\mathrm{CFU} / \mathrm{mL}$, respectively. The result indicated that the detection limit of SAT was significantly lower than real-time PCR after autoclaving.

\section{Discussion}

It was reported that most of invasive Cronobacter infections were in infants who were fed PIFs. So, PIFs were regarded as predominant sources of Cronobacter infections (Jason 2012) and the most likely media of transmission associated with hospital outbreaks (van Acker et al. 2001). Cronobacter contamination has been repeatedly found in PIF and factories producing it, and in the ingredients used to make PIF and factories processing these ingredients (Parra-Flores et al. 2018; Reich et al. 2010). During the processing, PIF is not sterile. So, some pathogens may be found in PIF, such as Cronobacter (Beuchat et al. 2009). If PIF is contaminated with Cronobacter, the mixture of PIF and water will become incubators of the bacteria, and then threaten the health of infants. Therefore, rapid, sensitive, simple and accurate techniques for early detection of viable Cronobacterspp. in PIFs are highly important and urgent to control the risk of Cronobacter related food-borne diseases (Zhu et al. 2012).

To date, a variety of detection and diagnostic approaches for detection of Cronobacter spp. have been developed and reported, such as the traditional isolation and biochemical identification directly from culture or after enrichment, or specific screening medium to characterize samples potentially contaminated (Cai et al. 2013). However, the current approved method for detection of Cronabacterspp. in PIFs is time-consuming, laborious and expensive due to the requirement of enrichment culture, incubation on selective media and phenotypic characterization (Druggan and Iversen 2009; International Organization for Standardization 2006b; Turcovsky et al. 2011).

At present, there are several rapid detection methods especially the molecular methods based on PCR amplification. DNA targeting molecular methods such as PCR, real-time PCR and LAMP, had many advantages over conventional approaches. Jaradat et al. (2009) indicated that Cronobacter spp. have high diversity and share a lot of phenotypic traits with other Enterobacteriaceae members. So, different chromogenic, biochemical, and molecular techniques was used to confirm the identity of this pathogen. The results revealed that $16 \mathrm{~s}$ rRNA sequencing should be used as a final confirmation and is pivotal to eliminate the doubts shed by the inability of other methods for identification and confirmation of the 
identity of the Cronobacter spp. Cai et al. (2013) developed an assay integrating real-time PCR and high resolution melting (HRM) analysis to specifically detect and rapidly identify Cronabacterspp. in PIF using OmpA gene. The method was proved to be sensitive with a detection limit of $10^{2} \mathrm{CFU} / \mathrm{mL}$ without preenrichment, and highly concordant with the accuracy of 100\% compared with ISO-IDF 22964 in 89 real samples (Cai et al. 2013). This method can need detect Cronobacterspp. in about $24 \mathrm{~h}$, which is far quicker than the up to 7 days of the currently routine procedure.

In the present study, we have developed a SAT method targeting 16s/23s rRNA for specific detection and rapid identification of viable Cronobacter spp. in PIFs and other foodstuffs. The SAT method developed in this study can detect Cronobacterspp. in about $1 \mathrm{~h} 20$ min without pre-enrichment, which is far quicker than the method developed in previous studies (Cai et al. 2013). Compared with other detection methods, the SAT method developed in this study has some advantages, such as (1) the amplification reaction is performed at a constant temperature, which can reduce the requirement for needing equipment; (2) the detection target is RNA, which has much higher concentration than DNA; (3) the amplification rate of RNA is much higher than that of DNA, which can shorten the detection time; (4) RNA is quickly degraded in dead bacteria, which can accurately distinguish viable Cronobacterspp. from the dead one; (5) the upstream and downstream primers and the probe is highly specific, which greatly improves the specificity of detection.

\section{Declarations}

\section{Ethics approval and consent to participate}

Not applicable

\section{Consent for publication}

Not applicable

\section{Availability of data and materials}

The datasets used and/or analyzed during the current study are available from the corresponding author on reasonable request.

\section{Competing interests}

The authors declare no conflict of interest. All authors have read and approved the final manuscript. 


\section{Funding}

This work was supported by Special Program for Guiding Local Science and Technology Development by the Central Government (19943003G).

\section{Authors' contributions}

RW, XL and FX conceived and designed the experiments; $X S, X G, G W, X W, W M, L Z$ and QL performed the experiments; RW, XS and FX analyzed the data; RW, XL and FX wrote the paper.

\section{Acknowledgments}

We gratefully acknowledge the financial support of Special Program for Guiding Local Science and Technology Development by the Central Government (19943003G). The funders had no role in the study design, data collection and analysis, decision to publish, or preparation of the manuscript.

\section{References}

Almeida C, Azevedo NF, Iversen C, Fanning S, Keevil CW, Vieira MJ (2009) Development and application of a novel peptide nucleic acid probe for the specific detection of Cronobacter genomospecies (Enterobacter sakazakii) in powdered infant formula. Appl Environ Microbiol 75(9):2925-2930

Barron JC, Forsythe SJ (2007) Dry stress and survival time of Enterobacter sakazakii and other Enterobacteriaceae in dehydrated powdered infant formula. J Food Prot 70(9):2111-2117

Beuchat LR, Kim H, Gurtler JB, Lin LC, Ryu JH, Richards GM (2009) Cronobacter sakazakii in foods and factors affecting its survival, growth, and inactivation. Int. J. Food Microbiol 136(2):204-213

Breeuwer P, Lardeau A, Peterz M, Joosten HM (2003) Desiccation and heat tolerance of Enterobacter sakazakii. J Appl Microbiol 95(5):967-973

Cai XQ, Yu HQ, Ruan ZX, Yang LL, Bai JS, Qiu DY, Jian ZH, Xiao YQ, Yang JY, Le TH, Zhu XQ (2013) Rapid detection and simultaneous genotyping of Cronobacterspp. (formerly Enterobacter sakazakii) in powdered infant formula using Real-time PCR and high resolution melting (HRM) analysis. PLoS One $8(6)$ e67082

Chen Y, Lampel K, Hammack T. Bacteriological Analytical Manual,Chapter 29:Cronobacter (2012) http://www.fda.gov/Food/FoodScienceResearch/LaboratoryMethods/ucm289378.htm/ Accessed 6 Jul 2019 
Commission CA (2008) Code of hygienic practice for powdered formulae for infants and young children. In (Vol. CAC/RCP $66-2008)$

Cruz-Córdova A, Rocha-Ramírez LM, Ochoa SA, Gónzalez-Pedrajo B, Espinosa N, Eslava C, HernándezChiñas U, Mendoza-Hernández G, Rodríguez-Leviz A, Valencia-Mayoral P, Sadowinski-Pine S, HernándezCastro R, Estrada-García I, Muñoz-Hernández O, Rosas I, Xicohtencatl-Cortes J (2012) Flagella from five Cronobacter species induce pro-inflammatory cytokines in macrophage derivatives from human monocytes. PLoS One 7(12):e52091

Druggan P, and Iversen C (2009) Culture media for the isolation of Cronobacterspp. Int J Food Microbiol 136(2):169-178

Edelson-Mammel SG, Porteous MK, Buchanan RL (2005) Survival of Enterobacter sakazakii in a dehydrated powdered infant formula. J Food Prot 68(9):1900-1902

Friedemann M (2009) Epidemiology of invasive neonatal Cronobacter(Enterobacter sakazakii) infections. Eur J Clin Microbiol Infect Dis 28(11):1297-1304

Geller M. FDA says no need to recall Enfamil formula. Reuters (2011). http://www.reuters.com/article/usmeadjohnsonidUSTRE7BL17R20111231\#zbiwXoWXUhfzEyUv.97/ Accessed 5 Jul 2019

International Organization for Standardization (2006a) Milk and milk products-Detection of Enterobacter sakazakii. In (Vol. ISO/TS 22964:2006|IDF/RM 210: 2006)

International Organization for Standardization (2006b). Specifies a method for the detection of Enterobacter sakazakii in milk and milk products. In (Vol. ISO-IDF 22964|IDF/RM 210: 2006)

Investigation of Cronobacter Infections, CDC Update: Investigation of Cronobacter Infections Among Infants in the United States. https://www.cdc.gov/cronobacter/investigation.html/ Accessed 5 Jul 2019

Iversen C, Mullane N, McCardell B, Tall BD, Lehner A, Fanning S, Stephan R, Joosten H (2008) Cronobacter gen. nov., a new genus to accommodate the biogroups of Enterobacter sakazakii, and proposal of Cronobacter sakazakii gen. nov., comb. nov., Cronobacter malonaticus sp. nov., Cronobacter turicensis sp. nov., Cronobacter muytjensii sp. nov., Cronobacter dublinensis sp. nov., Cronobacter genomospecies 1 , and of three subspecies, Cronobacter dublinensis subsp. dublinensis subsp. nov., Cronobacter dublinensis subsp. lausannensis subsp. nov. and Cronobacter dublinensis subsp. lactaridi subsp. nov. Int J Sys Evol Microbiol 58(Pt 6):1442-1447

Jackson EE, Forsythe SJ (2016) Comparative study of Cronobacteridentification according to phenotyping methods. BMC Microbiol 16:146

Jaradat ZW, Ababneh QO, Saadoun IM, Samara NA, Rashdan AM (2009) Isolation of Cronobacterspp. (formerly Enterobacter sakazakii) from infant food, herbs and environmental samples and the 
subsequent identification and confirmation of the isolates using biochemical, chromogenic assays, PCR and 16S rRNA sequencing. BMC Microbiol 9:225

Jason J (2012) Prevention of invasive Cronobacterinfections in young infants fed powdered infant formulas. Pediatrics 130(5):E1076-E1084

Lehner A, Tasara T, Stephan R (2004) 16S rRNA gene based analysis of Enterobacter sakazakii strains from different sources and development of a PCR assay for identification. BMC Microbiol 4:43

Liu X, Fang J, Zhang M, Wang X, Wang W, Gong Y, Xi X, Li M (2012) Development of a loop-mediated isothermal amplification assay for detection of Cronobacter spp. (Enterobacter sakazakii). World J Microbiol Biotechnol 28(3):1013-1020

Liu Y, Gao Q, Zhang X, Hou Y, Yang J, Huang X (2006) PCR and oligonucleotide array for detection of Enterobacter sakazakii in infant formula. Mol Cell Probes 20(1):11-17

Lv C, Jin J, Wang P, Dai X, Liu Y, Zheng M, Xing F (2019) Interaction of water activity and temperature on the growth, gene expression and aflatoxin production by Aspergillus flavus on paddy and polished rice. Food Chem 293:472-478

Minor T, Lasher A, Klontz K, Brown B, Nardinelli C, Zorn D (2015) The per case and total annual costs of foodborne illness in the United States. Risk Anal 35(6):1125-1139

Mohan Nair M K, Venkitanarayanan KS (2006) Cloning and sequencing of the ompA gene of Enterobacter sakazakii and development of an ompA-targeted PCR for rapid detection of Enterobacter sakazakii in infant formula. Appl Environ Microbiol 72(4):2539-2546

Mullane NR, Iversen C, Healy B, Walsh C, Whyte P, Wall PG, Quinn T, Fanning S (2007) Enterobacter sakazakii an emerging bacterial pathogen with implications for infant health. Minerva Pediatr 59(2):137148

O'Brien S, Healy B, Negredo C, Anderson W, Fanning S, Iversen C (2009) Prevalence of Cronobacter species (Enterobacter sakazakii) in follow-on infant formulae and infant drinks. Lett Appl Microbiol 48(5):536-541

Parra-Flores J, Aguirre J, Juneja V, Jackson EE, Cruz-Cordova A, Silva-Sanchez J, Forsythe S (2018) Virulence and antibiotic resistance profiles of Cronobacter sakazakii and Enterobacter spp. involved in the diarrheic hemorrhagic outbreak in Mexico. Front Microbiol 9: 2206

Reich F, Konig R, von Wiese W, Klein G (2010) Prevalence of Cronobacterspp. in a powdered infant formula processing environment. Int. J. Food Microbiol 140(2-3):214-217

Stoop B, Lehner A, Iversen C, Fanning S, Stephan R (2009) Development and evaluation of $r p o B$ based PCR systems to differentiate the six proposed species within the genus Cronobacter. Int $J$ Food Microbiol 
Turcovsky I, Kunikova K, Drahovska H, Kaclikova E (2011) Biochemical and molecular characterization of Cronobacter spp. (formerly Enterobacter sakazakii) isolated from foods. Anton. Leeuw. Int J G 99(2):257269

van Acker J, de Smet F, Muyldermans G, Bougatef A, Naessens A, Lauwers S (2001) Outbreak of necrotizing enterocolitis associated with Enterobacter sakazakii in powdered milk formula. J Clin Microbiol 39(1):293-297

Ye Y, Wu Q, Zhang J, Jiang H, Hu W (2012) Detection of viable Cronobacter spp. (Enterobacter sakazakii) by one-step RT-PCR in dry aquatic product. J of Food Sci 77(11):M616-M619

Zimmermann J, Schmidt H, Loessner MJ, Weiss A (2014) Development of a rapid detection system for opportunistic pathogenic Cronobacterspp. in powdered milk products. Food Microbiol 42:19-25

Zhu S, Schnell S, Fischer M (2012) Rapid detection of Cronobacterspp. with a method combining impedance technology and rRNA based lateral flow assay. Int J Food Microbiol 159(1):54-58

\section{Tables}

Table 1. Bacterial species and strains used in RT-LAMP-SAT assay 


\begin{tabular}{|c|c|c|}
\hline Species/Strains & $\begin{array}{l}\text { Strains } \\
\text { number }\end{array}$ & Source \\
\hline Cronobacter malonaticus & CICC21551 & China Center of Industrial Culture Collection \\
\hline Cronobacter dublinensis & CICC21564 & China Center of Industrial Culture Collection \\
\hline Cronobacter universalis & CICC21570 & China Center of Industrial Culture Collection \\
\hline Cronobacter muytjensii & CICC23943 & China Center of Industrial Culture Collection \\
\hline Cronobacter turicensis & CICC24178 & China Center of Industrial Culture Collection \\
\hline Cronobacter condimenti & CICC24184 & China Center of Industrial Culture Collection \\
\hline Citrobacter Freundii & ATCC8090 & American Type Culture Collection \\
\hline Enterobacter cloacae & CICC10011 & China Center of Industrial Culture Collection \\
\hline Enterococcus faecalis & CICC10396 & China Center of Industrial Culture Collection \\
\hline Escherichia coli & ATCC25922 & American Type Culture Collection \\
\hline Klebsiella peneumoniae & CICC21519 & China Center of Industrial Culture Collection \\
\hline Listeria monocytogenes & CMCC54001 & $\begin{array}{l}\text { National Center for Medical Culture } \\
\text { Collections }\end{array}$ \\
\hline Listeria welshimeri & CICC21672 & China Center of Industrial Culture Collection \\
\hline Listeria innocua & CICC 10417 & China Center of Industrial Culture Collection \\
\hline Proteus vulgaris & $\mathrm{CMCC}(\mathrm{B}) 49027$ & $\begin{array}{l}\text { National Center for Medical Culture } \\
\text { Collections }\end{array}$ \\
\hline Pseudomonas aeruginosa & $\mathrm{ABCC} 0927$ & China Center of Industrial Culture Collection \\
\hline Salmonella paratyphi $B$ & CICC21495 & China Center of Industrial Culture Collection \\
\hline Salmonella paratyphi-A & CICC21501 & China Center of Industrial Culture Collection, \\
\hline Salmonella enteritidis & CMCC(B) 5004 & $\begin{array}{l}\text { National Center for Medical Culture } \\
\text { Collections }\end{array}$ \\
\hline Salmonella typhimurium & CMCC(B) 50115 & $\begin{array}{l}\text { National Center for Medical Culture } \\
\text { Collections }\end{array}$ \\
\hline Shigella flexneri & CICC10865 & China Center of Industrial Culture Collection \\
\hline Shigella dysenteriae & CICC10865 & China Center of Industrial Culture Collection \\
\hline Shigella sonnei & CICC 21535 & China Center of Industrial Culture Collection \\
\hline Shigella castellani & CMCC(B) 51572 & National Center for Medical Culture \\
\hline
\end{tabular}




\section{Collections}

Staphylococcus aureus

Staphylococcus xylosus

Staphylococcus epidermidis

Vibrio parahaemolyticus

Vibrio

parahaemolyticus

Vibrio vulnificus

Yersinia pseudotuberculosis
ATCC25923

CICC20237

CICC10294

CICC21528

ATCC17802

CICC21615

CICC21669
American Type Culture Collection

China Center of Industrial Culture Collection

China Center of Industrial Culture Collection

China Center of Industrial Culture Collection

American Type Culture Collection

China Center of Industrial Culture Collection

China Center of Industrial Culture Collection

Table 2 Comparison of pre-enrichment time between SAT and Real-Time PCR 


\begin{tabular}{|c|c|c|c|c|c|c|c|c|c|c|c|}
\hline \multicolumn{2}{|c|}{ concentration $₫ \mathrm{CFU} / \mathrm{mL} \square$} & $1 \mathrm{~h}$ & $2 \mathrm{~h}$ & $3 \mathrm{~h}$ & $4 h$ & $5 \mathrm{~h}$ & $6 h$ & $7 \mathrm{~h}$ & $8 \mathrm{~h}$ & $9 \mathrm{~h}$ & $10 \mathrm{~h}$ \\
\hline \multirow[t]{8}{*}{$\mathrm{SAT}$} & Blank & - & - & - & - & - & - & - & - & - & - \\
\hline & $10^{-3}$ & - & - & - & - & - & - & - & + & + & + \\
\hline & $10^{-2}$ & - & - & - & - & - & - & - & + & + & + \\
\hline & $10^{-1}$ & - & - & - & + & + & + & + & + & + & + \\
\hline & $10^{0}$ & - & - & + & + & + & + & + & + & + & + \\
\hline & $10^{1}$ & - & + & + & + & + & + & + & + & + & + \\
\hline & $10^{2}$ & + & + & + & + & + & + & + & + & + & + \\
\hline & $10^{3}$ & + & + & + & + & + & + & + & + & + & + \\
\hline \multirow[t]{8}{*}{ Real-timePCR } & Blank & - & - & - & - & - & - & - & - & - & - \\
\hline & $10^{-3}$ & - & - & - & - & - & - & - & - & - & - \\
\hline & $10^{-2}$ & - & - & - & - & - & - & - & - & - & - \\
\hline & $10^{-1}$ & - & - & - & - & - & - & - & + & + & + \\
\hline & $10^{0}$ & - & - & - & - & + & + & + & + & + & + \\
\hline & $10^{1}$ & - & - & - & + & + & + & + & + & + & + \\
\hline & $10^{2}$ & - & - & + & + & + & + & + & + & + & + \\
\hline & $10^{3}$ & + & + & + & + & + & + & + & + & + & + \\
\hline
\end{tabular}

Figures 

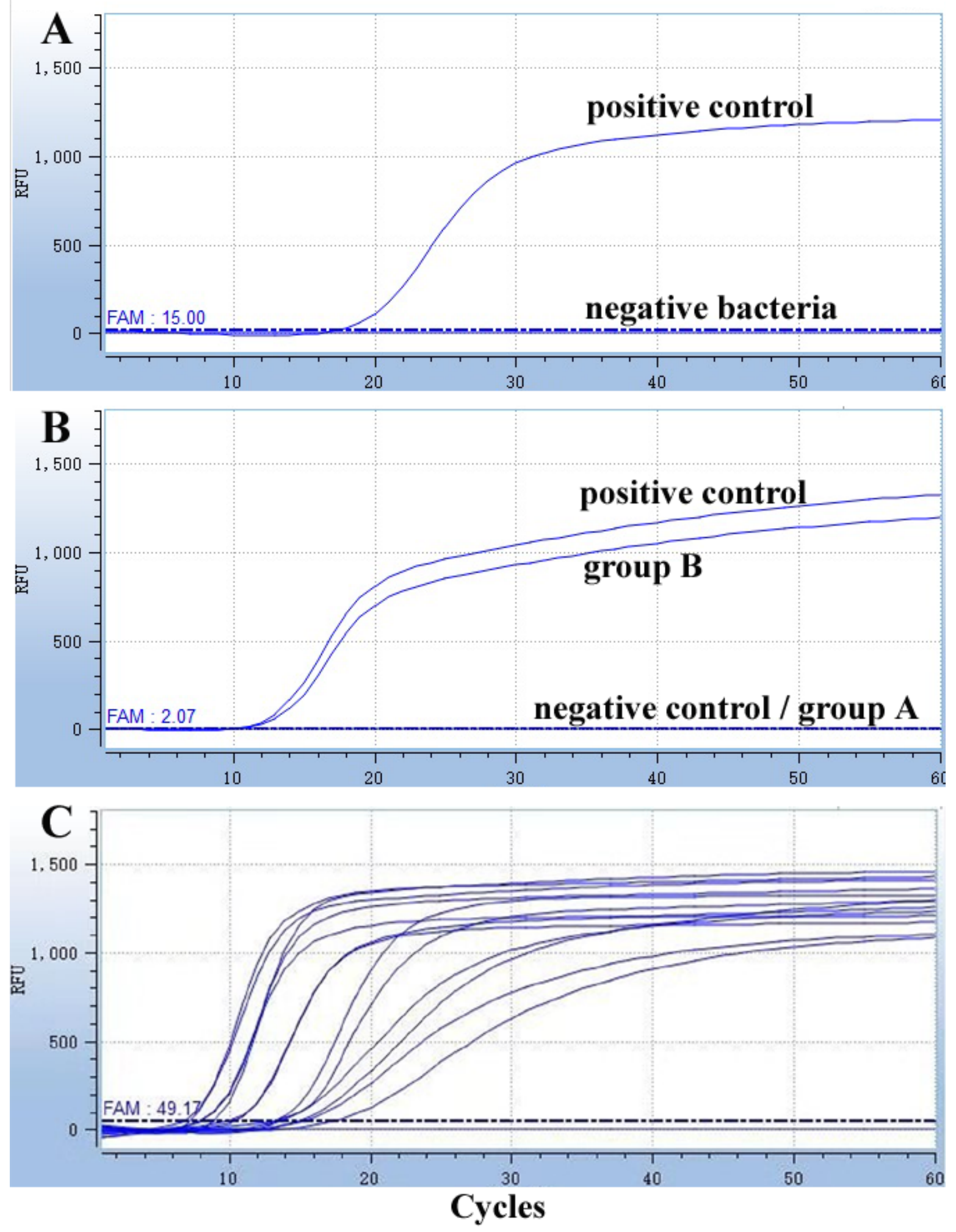

Figure 1

SAT analysis for all bacterial strains. (A) SAT amplification for positive control (C. sakazikii) and negative bacteria (non-C. sakazikii). (B) SAT amplification for positive control (C. sakazikii), group B (the mixed strains of $C$. sakazikii and non-C. sakazikii strains) and group A (the mixed culture of non-C. sakazakii strains). (C) SAT amplification for 6 C. sakazakii strains. 

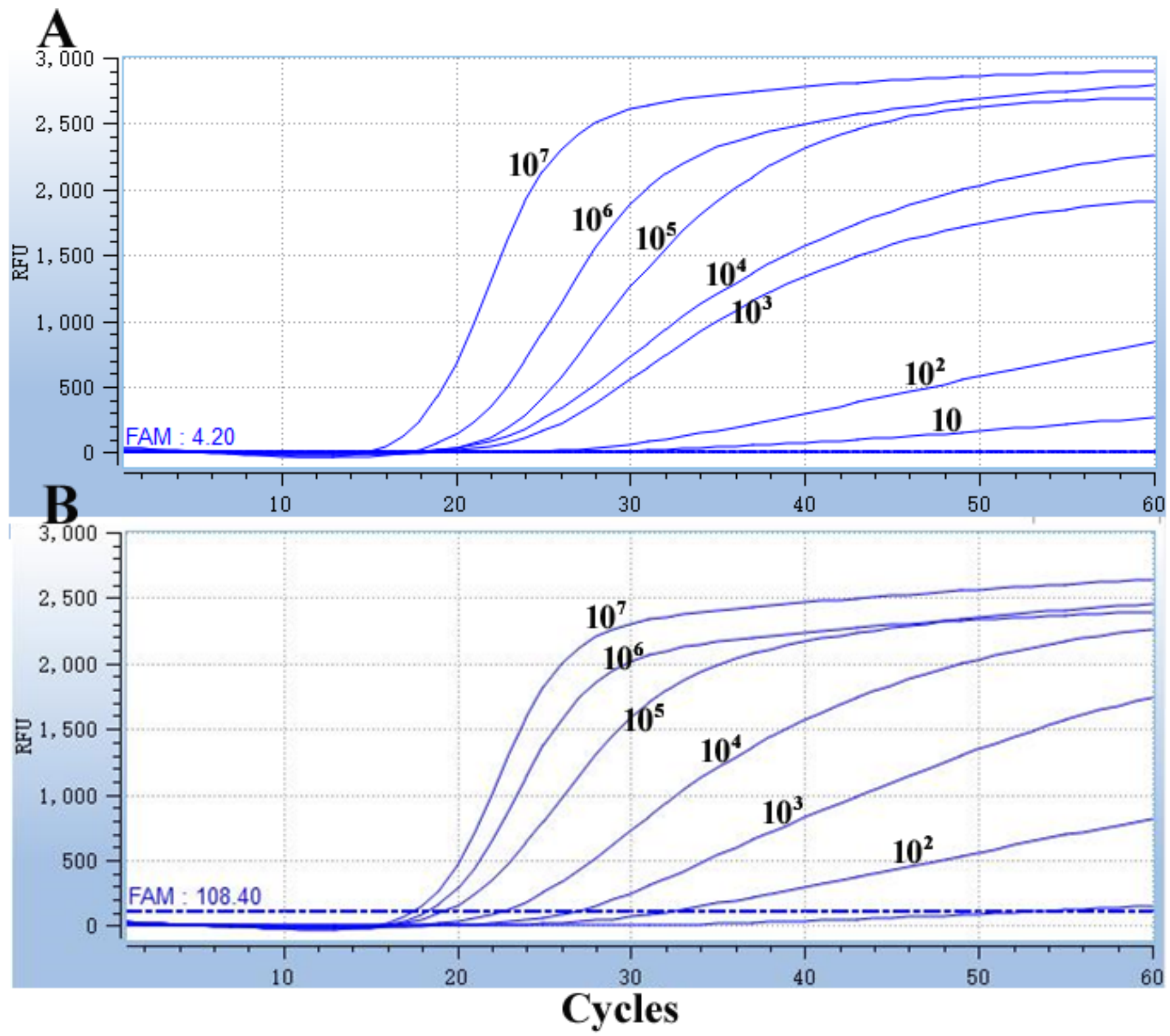

Figure 2

SAT analysis of 10 -fold serial dilution of $\mathrm{C}$. sakazakii in pure culture and in powdered infant formula. (A) Pure culture. (B) Powdered infant formula. 

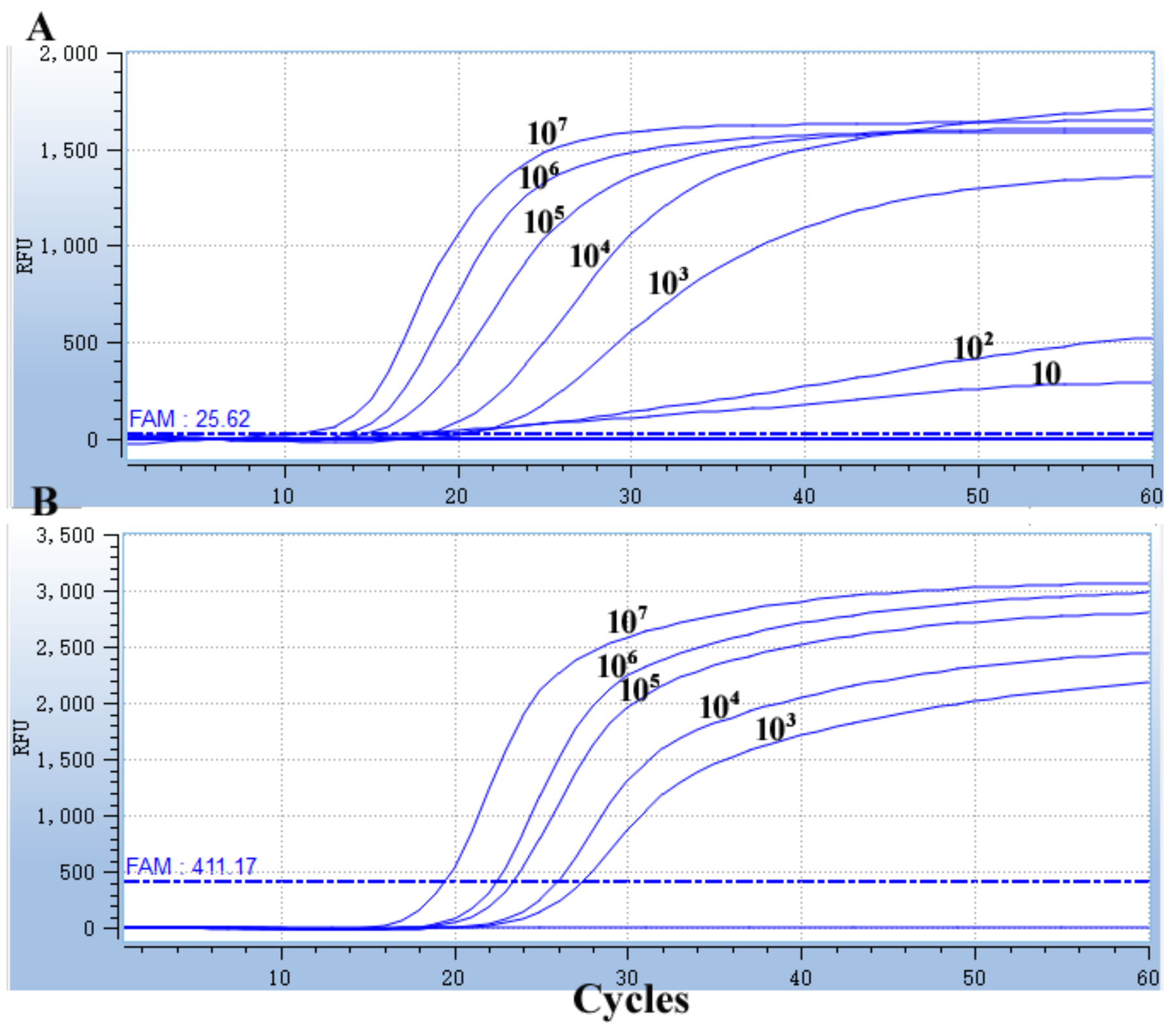

\section{Figure 3}

The detection limits of SAT and Real-time analysis without enrichment. (A) SAT analysis. (B) Real-time PCR analysis. 


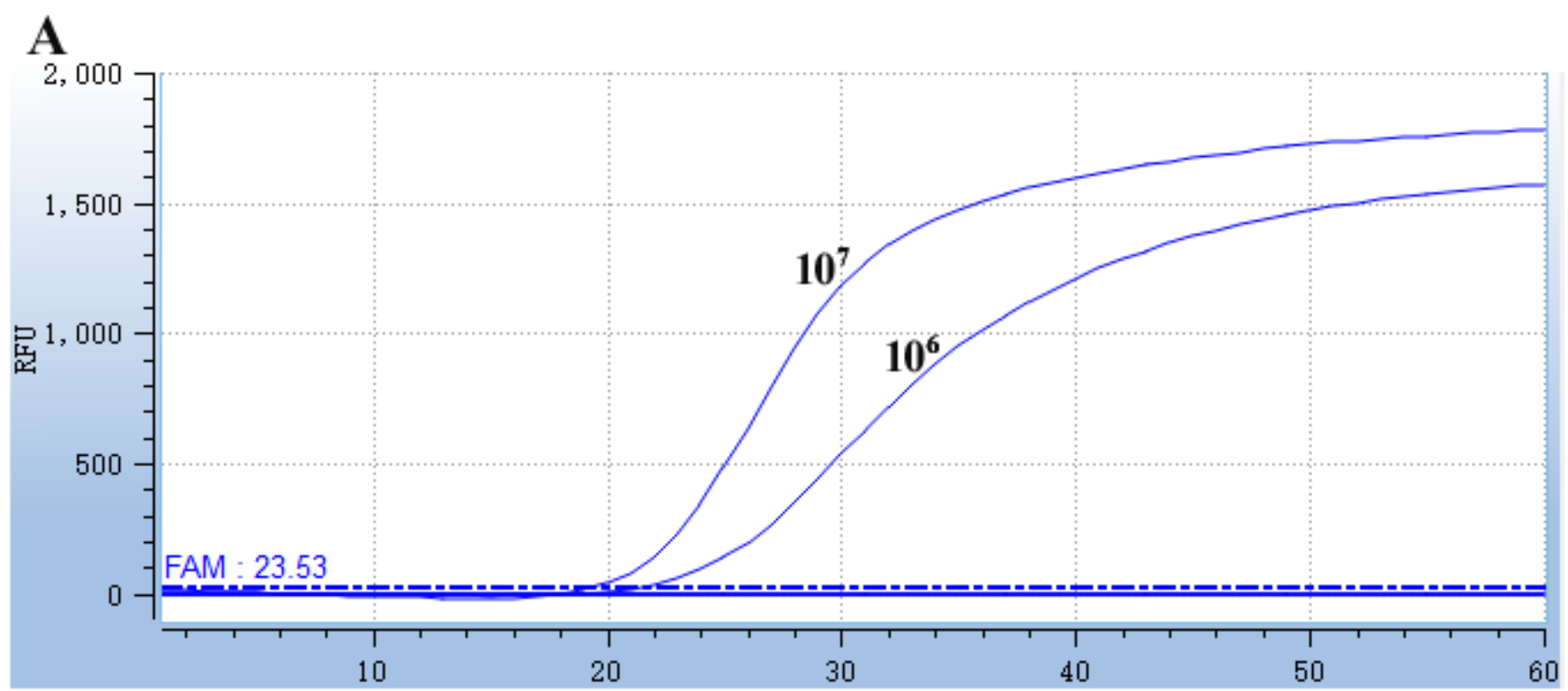

B

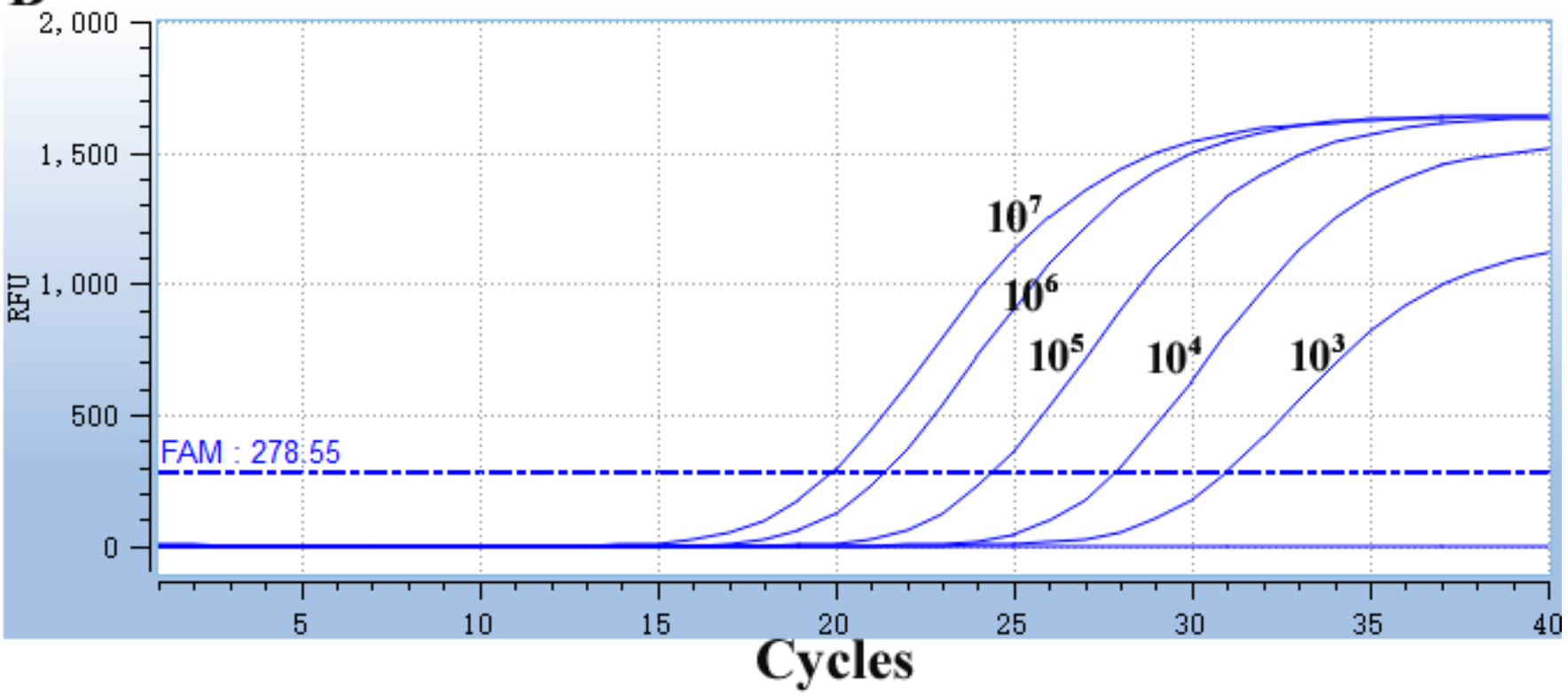

Figure 4

The viable bacteria detection of SAT and Real-time PCR analysis. (A) SAT analysis. (B) Real-time PCR analysis. 